\title{
Microbiological Quality of Meat and Swabs from Contact Surface in Butcher Shops in Debre Berhan, Ethiopia
}

\author{
Tefera Atlabachew and Jermen Mamo \\ Department of Biology, College of Natural and Computational Science, Debre Berhan University, Debre Berhan, Ethiopia \\ Correspondence should be addressed to Jermen Mamo; jermenmamo@yahoo.com
}

Received 12 April 2021; Accepted 19 July 2021; Published 9 August 2021

Academic Editor: Efstathios Giaouris

Copyright ( 92021 Tefera Atlabachew and Jermen Mamo. This is an open access article distributed under the Creative Commons Attribution License, which permits unrestricted use, distribution, and reproduction in any medium, provided the original work is properly cited.

\begin{abstract}
Food-borne pathogens are the primary source of infection in developing countries. The widespread practice of raw beef consumption was a potential cause of food-borne diseases in Ethiopia. Hence, this study was initiated to assess the microbiological quality of fresh meat samples from butcher shops in Debre Berhan. Fresh meat samples and swab samples from contact surfaces were collected from butcher shops for microbial analysis, following standard methods. The study revealed that the mean microbial counts of morning samples for total aerobic mesophilic, Staphylococci, Enterobacteriaceae, total coliform, fecal coliform, aerobic spore formers, and yeasts and molds of the butcher shops were 5.31, 4.24, 4.47, 4.79, 4.74, 3.77, and 5.0 log cfu/g, respectively. The mean microbial counts from the afternoon sample for total aerobic mesophilic, Staphylococci, Enterobacteriaceae, total coliform, fecal coliform, aerobic spore formers, and yeasts and molds of the butcher shops were 5.47, 4.78, 4.84, 4.88, 4.94, 5.15, and 5.07 log $\mathrm{cfu} / \mathrm{g}$, respectively. A higher microbial load was found from the meat sample collected in the afternoon. The mean microbial counts of total aerobic mesophilic, Staphylococci, Enterobacteriaceae, total coliform, fecal coliform, aerobic spore formers, and yeasts and molds from swabs of the contact surface were 4.17, 3.98, 4.08, 3.96, 3.86, 3.80, and $3.92 \mathrm{log} \mathrm{cfu} / \mathrm{cm}^{2}$, respectively. Further characterization of the aerobic mesophilic flora indicated a dominance by Enterobacteriaceae (36\%) followed by Staphylococci spp. (24\%) and Bacillus spp. (19\%). The prevalence of S. aureus, E. coli, and Salmonella in meat and swab samples was 37.5\%, 32.5\%, and $7.5 \%$, respectively. In this study, it was observed that all samples collected from butcher shops detected a significant count of spoilage microbes. Hence, adequate sanitary measures should be taken from production to consumption stages.
\end{abstract}

\section{Introduction}

Foodborne diseases are usually caused by bacteria, parasites, viruses, or toxins $[1,2]$. Foodborne diseases vary between countries depending on food consumption, food processing, preparation, handling, storage techniques employed, and sensitivity of the population [3]. However, the highest prevalence of foodborne outbreaks is commonly found in developing countries. Food-borne diseases associated with raw beef meat remain the most significant food safety hazards worldwide [4].

The most common genera of meat spoilage bacteria are Staphylococcus, Bacillus, Campylobacter, Clostridium, Listeria, Salmonella, lactic acid bacteria, Pseudomonas spp.,
Acinetobacter spp., and Moraxella spp. that can cause discoloration, bad odors, and slime on beef surfaces [5]. Mold species found in meat include Cladosporium, Geotrichum, Penicillium, and Mucor while yeast species include Candida spp. and Cryptococcus spp. [6]. Even though the storage conditions affect the type of microbes found in meat, slime formation, structural components degradation, biochemical change, off-odor, and appearance change were found in meat as a result of spoilage microorganisms [7].

The meat could be contaminated with microbes during slaughter and/or processing. The contaminating organisms are mainly derived from animal hide and feces. Processed meat can also be contaminated with pathogenic microorganisms from the environment during the various stages of processing [8]. 
In mild-to-severe illness, hospitalization or even death can be caused by the ingestion of infected food [9]. Recent data from either developing or developed countries showed that about $10 \%$ of the population may experience foodborne diseases. The situation is equally serious in developing countries, with obvious economic consequences [10]. Infected food handlers are an important source of foodborne diseases in developed countries [11].

The consumption of animal-origin food such as meats, fish, and their products especially in their raw state is generally regarded as high-risk products [12]. In Ethiopia, a habit of consuming beef at its raw or partially cooked state is common which may be a potential cause of foodborne illnesses [13]. This could be due to poor food handling and sanitation practices, inadequate food safety regulations, weak regulatory systems, and a lack of education for food handlers [14]. The meat handling and processing practices implemented in some butcher shops at Debre Berhan may provide a chance in which many spoilage microorganisms can easily grow on it and cause spoilage and food-borne disease. Therefore, the microbiological quality of meat should be assessed to devise hygienic practices implemented in butcheries to reduce food-borne disease caused by consuming spoiled products. Thus, the main objective of the study was to evaluate the microbiological quality of meat and contact surface sold in butchery shops at Debre Berhan, Ethiopia.

\section{Materials and Methods}

2.1. Description of the Study Area. The study was conducted in Debre Berhan which is about $130 \mathrm{~km}$ far from Addis Ababa, the capital city of the country. It has an elevation of 2840 meters and latitude and longitude $\left(9041^{\prime} \mathrm{N} 39032^{\prime} \mathrm{E}\right)$. Debre Berhan has a total population of 160,408 based on the 2012 national census conducted by the central statistical Agency Ethiopia [15].

2.2. Study Design. A systematic random sampling method was used to assess the microbiological quality of meat in butcher shops in Debre Berhan. For this study, fresh beef meat samples were collected from several butcher shops and intended for microbiological analysis.

2.3. Questionnaire and Observational Survey. The survey was conducted using questionnaires and visual observations. Semistructured questionnaires were prepared and filled in by food handlers and consumers in the butchers' shops to assess their knowledge, attitudes, and practices towards hygienic meat processing. A total of 16 respondents (two from each butchery shop) and 50 consumers were provided with the questionnaires to collect their responses. Level of education, exposure to training, experience of using hair cover and jewelery, the way of money handling, and personal hygiene were included in the questionnaires. A preliminary survey was conducted before the actual study to prepare and manage the relevant questionnaire.
2.4. Samples Collection. A total of 40 samples, 16 fresh beef samples ( $250 \mathrm{~g}$ each), and 24 swabs samples were collected from 8 randomly selected butcher shops, aseptically using sterile polythene plastic bags. The swab samples were taken from knives, weighing balance, and cutting tables with an area of $1 \mathrm{~cm}^{2}$ using sterile swabs soaked into a $0.1 \%$ saline solution. Samples were then transported to Debre Berhan University microbiology laboratory using an icebox $\left(4^{\circ} \mathrm{C}\right)$ for immediate analysis. Fresh beef samples were collected at two distinct times of the day, early in the morning (8:00-9:00 am) and late in the afternoon (5:00-6:00 pm) $[16,17]$.

2.5. Sample Preparation. Twenty-five grams (25g) of the meat samples were weighed and transferred to a stomacher bag under aseptic conditions. The samples were then diluted to $10^{-1}$ using $225 \mathrm{~mL}$ peptone water and homogenized for 2 min by using a Stomacher. Following homogenization, further serial dilutions were made using sterile peptone water. On the other hand, each tube containing swab samples $(10 \mathrm{~mL}$ of $0.1 \%$ saline water $)$ was vortexed to ensure a mixture of the sample. A tenfold serial dilution was prepared by transferring $1 \mathrm{~mL}$ of the homogenized sample (both meat and swab) to $9 \mathrm{~mL}$ diluents. From appropriate serial dilutions, a $0.1 \mathrm{~mL}$ aliquot was plated on various types of media for microbial counts $[16,17]$.

2.5.1. Total Aerobic Mesophilic Count (TAMC). A $0.1 \mathrm{~mL}$ of an aliquot from appropriate dilution was pipetted and spread on standard predried plate count agar media. Inoculated plates were incubated at $32^{\circ} \mathrm{C}$ for $48-72 \mathrm{hrs}$. After incubation, the plates with colonies between 30 and 300 were counted using colony counter [18].

2.5.2. Total Coliforms and Fecal Coliform Count. A $0.1 \mathrm{~mL}$ of an aliquot from appropriate dilution was pipetted and spread on Violet Red Bile Agar. The inoculated plates were then incubated at $32^{\circ} \mathrm{C}$ for $18-24$ hrs to determine total coliforms and at $44.5^{\circ} \mathrm{C}$ for $18-24 \mathrm{hrs}$ to determine fecal coliform [19].

2.5.3. Enterobacteriaceae Count. To count the members of Enterobacteriaceae, $0.1 \mathrm{~mL}$ of the aliquot from appropriate dilution was spread plated on MacConkey agar (M $081 \mathrm{Hi}-$ Media, Mumbai) supplemented with glucose and was incubated at $35^{\circ} \mathrm{C}$ for $24 \mathrm{hrs}$. All reddish purple/pink colonies were counted as members of the Enterobacteriaceae [19].

2.5.4. Aerobic Spore Formers. For aerobic spore-forming bacteria, the meat sample suspension was first heated at $80^{\circ} \mathrm{C}$ in the water bath for ten min to kill vegetative cells. Then, $0.1 \mathrm{~mL}$ of the homogenate was spread plated on the predried surface of plate count agar (PCA) plates. Colonies were counted after incubation at $35^{\circ} \mathrm{C}$ for 36 to $72 \mathrm{hrs}$.

2.5.5. Total Fungal Counts. The yeasts and molds count was done by direct plate count using Potato Dextrose Agar (M 091 Hi-Media, Mumbai) supplemented with $0.1 \mathrm{~g}$ of 
chloramphenicol as an antibacterial agent. A $0.1 \mathrm{~mL}$ from the appropriate dilution was spread plated on PDA. Total yeasts and molds were counted after incubation at $25^{\circ} \mathrm{C}$ for 3-5 days [20].

\subsection{Detection of Pathogenic Microorganisms}

2.6.1. Total Staphylococcus spp. Count. Staphylococcus species were enumerated by pour plate method and grown on Mannitol Salt Agar (MSA). 0.1 mL aliquot from the appropriate dilution was inoculated into predried MSA plates. The inoculated plates were incubated at $37^{\circ} \mathrm{C}$ for $24 \mathrm{hrs}$. After incubation, yellow colonies were counted and recorded as Staphylococcus counts using the colony counter [19].

2.6.2. Detection of Escherichia coli. E. coli species were isolated using MacConkey agar (Hi-Media, Mumbai, India). $0.1 \mathrm{~mL}$ of the sample was spread into MacConkey agar plates and incubated at $37^{\circ} \mathrm{C}$ for $24 \mathrm{hrs}$. The colonies were confirmed by streaking 2-3 colonies onto MacConkey agar and colonies were further confirmed by Gram's staining and by biochemical tests $[21,22]$.

2.6.3. Detection of Salmonella spp. A $25 \mathrm{~g}$ of meat sample (minced by stomacher) was transferred to $225 \mathrm{~mL}$ of Buffered Peptone Water (BPW) and incubated at $37^{\circ} \mathrm{C}$ for $24 \mathrm{hrs}$. An aliquot of $0.1 \mathrm{~mL}$ from perenrichment was pipetted to $10 \mathrm{~mL}$ tetrathionate broth (supplement with iodine). A loopful sample from tetrathionate culture was streaked onto $\mathrm{SS}$ agar plates. The plates were incubated at $37^{\circ} \mathrm{C}$ for $24 \mathrm{hrs}$. After 24 hrs of incubation, the formation of colonies with black centers or with gray colors on SS agar was considered as presumptive Salmonella spp. [23, 24].

2.7. Determination of Microbial Load. Appropriate plates containing distinct microbial colonies were selected and counted using a colony counter. Then, the microbial load was determined using the standard formula as follows [25]:

$$
N=\frac{n}{s \times d}
$$

where $N=$ total number of bacteria (cfu) per gram of the sample, $n=$ average number of bacterial colonies, from different dilutions in Petri dish that contained 30-300 colonies, $s=$ volume of sample for plating, and $d=$ dilution factor of the specimen/food sample.

2.8. Characterization of Dominant Microorganism. After enumeration, from plate count agar (total aerobic mesophilic bacteria), about 5 colonies were picked randomly from countable plates and inoculated into tubes containing about $5 \mathrm{~mL}$ nutrient broth. These were then incubated at $30^{\circ} \mathrm{C}$ overnight. The cultures were purified by repeated streak plating and characterized using morphological and biochemical tests [26].

\subsubsection{Morphological Characterization of Dominant Bacteria}

(1) Cell Shape and Cell Arrangement. From overnight pure broth culture, the wet mount was prepared on a microscope slide and stained using methylene blue. The stained microbial cells were then observed under a light microscope using an oil immersion objective (x100). The morphological criteria considered during the observation were cell shape (spherical, rod, spiral, etc.) and cell arrangement (single, pair, chain, clusters, and tetrads) [27].

(2) Gram Reaction (KOH Test). The $\mathrm{KOH}$ test was conducted according to the method of Gregerson [28]. Twenty-fourhour-old pure culture colony picked from the plate count agar was placed on a clean slide and stirred with two drops of $3 \%$ $\mathrm{KOH}$ for about $2 \mathrm{~min}$. The Gram-negative mass was allowed to rise with inoculating needle following the loop to raise 0.5 to $2 \mathrm{~cm}$ or more whereas the Gram-positives did not show slime.

\subsubsection{Biochemical Tests}

(1) Catalase Test. Young colonies are flooded with a 3\% solution of hydrogen peroxide. The formation of bubbles was considered as the presence of catalase [26].

2.9. Biochemical Tests for Escherichia coli sp. The presence of E. coli spp. was confirmed using indole and MRVP test $[22,26]$.

2.10. Detection of Staphylococcus aureus. For identification of $S$. aureus, a loopful of the sample from the homogenate was inoculated onto Mannitol salt agar. Then, golden-yellow colonies on MSA which showed catalase-positive and coagulase-positive were considered as $S$. aureus. The biochemical tests (catalase and coagulase) were done as a confirmatory test [19].

2.11. Biochemical Tests for Salmonella spp. The biochemical test for Salmonella spp. was conducted using Triple Sugar Iron Agar test [22, 26], Lysine Iron Agar test ([24] and ISO, 6579), and Simmons Citrate Agar test.

2.12. Data Analysis. The data analyses were performed using Statistical Package for Social Sciences (SPSS) version 20. One-way ANOVA and LSD were performed for mean comparison at $P \leq 0.05$ using the same program [29].

\section{Results}

3.1. Observation and Questionnaire Survey. The data were collected from 16 meat handlers (13 men and 3 women) working at 8 butcher shops using questioners and visual observations (Tables 1 and 2). Out of the total participants, 5 were illiterate while the remaining 11 completed primary school (Table 1). Regarding the training experience, only 4 (25\%) out of 16 participants had taken training on sanitary practices. Only 5 out of 16 participants had renewed their 
TABLE 1: Survey on knowledge of butchers on hygienic practices in Debre Berhan town.

\begin{tabular}{|c|c|c|c|}
\hline Variables & Value & Frequency & Percent \\
\hline \multirow{2}{*}{ Sex } & Male & 13 & 81 \\
\hline & Female & 3 & 19 \\
\hline \multirow{3}{*}{ Educational level } & Illiterate & 3 & 19 \\
\hline & Primary school & 11 & 68 \\
\hline & High school & 2 & 13 \\
\hline \multirow{2}{*}{ Experience of training } & Yes & 4 & 25 \\
\hline & No & 12 & 75 \\
\hline \multirow{2}{*}{ Health certificate } & Yes & 5 & 31 \\
\hline & No & 11 & 69 \\
\hline \multirow{2}{*}{ Clean overcoat } & Yes & 12 & 75 \\
\hline & No & 4 & 25 \\
\hline \multirow{2}{*}{ Hair cover } & Yes & 9 & 56 \\
\hline & No & 7 & 44 \\
\hline \multirow{2}{*}{ Wearing watch and jeweleries } & Yes & 6 & 37 \\
\hline & No & 10 & 63 \\
\hline \multirow{2}{*}{ Skin rash, skin boils, cut, diarrhea, and vomiting } & Yes & 3 & 19 \\
\hline & No & 13 & 81 \\
\hline
\end{tabular}

health certificates. Concerning their hygiene, $75 \%$ of the meat handlers wore clean overcoats and while $56 \%$ used hair covers (Table 1). On the other hand, only $19 \%$ of the food handlers had a skin rash, skin boils, and/or skin cut (Table 1).

A total of 50 respondents participated in this study by providing their opinion and experiences related to sanitary practices used in the butcher's shop. Out of the total respondents, $41(82 \%)$ and $9(18 \%)$ were male and female, respectively. Twelve (24\%) respondents completed secondary school whereas $19(38 \%)$ respondents completed college and above. Most 38 (76\%) of the respondents prefer beef to other types of red meat and $44(88 \%)$ of them preferred fresh meat for consumption. Only 4 (8\%) of the respondents considered the healthiness of the meat (Table 3). 42 (84\%) of the respondents showed the habit of raw meat consumption. More than half (58\%) of the respondents did not recognize fecal-oral pathogen transmission. About $44 \%$ of the respondents suffered from food poisoning, of which $17(34 \%)$ required medical attention and took antibiotics for recovery (Table 3 ).

\subsection{Microbial Dynamics in Meat and Contact Surface for Samples Collected from Butcher Shops}

3.2.1. The Microbial Load of Meat. The mean total aerobic mesophilic bacteria (TAMC), aerobic spore formers (ASFC), Enterobacteriaceae (EBC), total coliform (TCC), fecal coliform (FCC), total Staphylococci (TSC), and yeast and mold (YMC) in the meat collected during the morning and afternoon periods were found between 5.31 and $5.47 \log \mathrm{cfu} / \mathrm{g}$, 3.77 and $5.15 \log \mathrm{cfu} / \mathrm{g}, 4.47$ and $4.84 \log \mathrm{cfu} / \mathrm{g}, 4.79$ and 4.88 $\log \mathrm{cfu} / \mathrm{g}, 4.74$ and $4.94 \log \mathrm{cfu} / \mathrm{g}, 4.24$ and $4.78 \mathrm{log} \mathrm{cfu} / \mathrm{g}$, and 5.0 and $5.07 \log \mathrm{cfu} / \mathrm{g}$, respectively (Table 4 ). In all the cases, higher microbial counts were detected from beef meat samples collected in the afternoon as compared to the morning.
3.2.2. The Microbial Load of Swabs from the Contact Surface of Butcher Shops. Mean total aerobic mesophilic bacteria (4.17-4.84 $\left.\log \mathrm{cfu} / \mathrm{cm}^{2}\right)$, aerobic spore formers (3.80-4.74 $\left.\log \mathrm{cfu} / \mathrm{cm}^{2}\right)$, Enterobacteriaceae $\left(4.08-4.26 \log \mathrm{cfu} / \mathrm{cm}^{2}\right)$, total coliform (3.67-4.41 $\log \mathrm{cfu} / \mathrm{cm} 2)$, fecal coliform (3.86-3.94 log cfu/ $\mathrm{cm}^{2}$ ), total Staphylococci (3.98-4.81 log $\mathrm{cfu} / \mathrm{g})$, and yeast and mold (3.61-4.53 $\log \mathrm{cfu} / \mathrm{cm}^{2}$ ) were detected from contact surfaces (knife, cutting table, and balance) (Table 5). The highest count for all groups of microorganisms was noticed from knife swabs except for Enterobacteriaceae and fecal coliform. On the other hand, the maximum counts for Enterobacteriaceae and coliform were detected from the cutting table and balance, respectively.

3.2.3. Prevalence of Pathogenic Microorganisms and Distribution. A food-borne illness caused by nontyphoid Salmonella, S. aureus, and E. coli represents a major public health problem worldwide. These pathogens are transmitted mainly through the consumption of contaminated food and the presence of these organisms in raw meat products have relevant public health implications. In this study pathogens like Salmonella, S. aureus, and E. coli were identified using different biochemical tests such as catalase, oxidase, triple sugar iron, Simmons citrate, lysine iron agar, motility, indole, methyl red, gas production, $\mathrm{H}_{2} \mathrm{~S}$ production, acid production, coagulase, and gram reaction test (Table 6).

A total of 40 samples (16 beef meat and 24 swabs from contact surfaces) were analyzed to check the presence of pathogenic microorganisms. According to the biochemical test result in Figure 1, 15 (37.5\%), 13 (32.5\%), and 3 (7.5\%) samples were presumptively detected as positive for S. aureus, E. coli, and Salmonella spp., respectively. In all the cases, the maximum positive samples were detected from beef meat in comparison to samples from contact surfaces. 
TABLE 2: Hygienic data collected from the butcher shops by visual observation.

\begin{tabular}{|c|c|c|c|}
\hline Variables & Value & Frequency & Percent \\
\hline \multirow{2}{*}{ Means of money collection } & Cashier & 5 & 63 \\
\hline & Butchers & 3 & 37 \\
\hline \multirow{2}{*}{ Refrigerator usage } & Yes & 0 & 0 \\
\hline & No & 8 & 100 \\
\hline \multirow{3}{*}{ General sanitation of the shop } & Better & 2 & 20 \\
\hline & Good & 1 & 17 \\
\hline & Poor & 5 & 63 \\
\hline \multirow{2}{*}{ Location of the toilet and possibility of contamination } & Yes & 2 & 20 \\
\hline & No & 6 & 80 \\
\hline \multirow{2}{*}{ Availability of soap for washing hands } & Yes & 0 & 0 \\
\hline & No & 8 & 100 \\
\hline
\end{tabular}

TABLE 3: Consumers' knowledge, attitudes, and practices regarding meat preference and foodborne diseases.

\begin{tabular}{|c|c|c|c|}
\hline Variables & Value & Frequency & Percent \\
\hline \multirow{2}{*}{ Sex } & Male & 41 & 82 \\
\hline & Female & 9 & 18 \\
\hline \multirow{4}{*}{ Education status } & Illiterate & 11 & 22 \\
\hline & Primary school & 8 & 16 \\
\hline & High school & 12 & 24 \\
\hline & College and above & 19 & 38 \\
\hline \multirow{3}{*}{ Age } & $15-30$ & 13 & 26 \\
\hline & $31-50$ & 21 & 42 \\
\hline & Above 50 & 16 & 32 \\
\hline \multirow{3}{*}{ Priority criteria } & Freshness & 44 & 88 \\
\hline & Healthiness & 4 & 8 \\
\hline & Cheapness & 2 & 4 \\
\hline \multirow{2}{*}{ Red meat you prefer } & Beef & 38 & 76 \\
\hline & Mutton & 12 & 24 \\
\hline \multirow{2}{*}{ Do you consume raw beef } & Yes & 42 & 84 \\
\hline & No & 8 & 16 \\
\hline \multirow{4}{*}{ How often do you consume } & Every day & 0 & 0 \\
\hline & Once in week & 17 & 34 \\
\hline & 1-3 times a week & 1 & 2 \\
\hline & Once per month & 32 & 64 \\
\hline \multirow{2}{*}{ History of food infection } & Yes & 22 & 44 \\
\hline & No & 28 & 56 \\
\hline \multirow{3}{*}{ Symptoms shown } & Vomiting & 6 & 12 \\
\hline & Abdominal cramp & 27 & 54 \\
\hline & Nonbloody diarrhea & 17 & 34 \\
\hline \multirow{3}{*}{ Types of action taken } & Drug & 17 & 34 \\
\hline & Traditional & 21 & 42 \\
\hline & None & 12 & 24 \\
\hline \multirow{2}{*}{ Pathogen transmitted by meat consumption } & Yes & 21 & 42 \\
\hline & No & 29 & 58 \\
\hline
\end{tabular}

3.2.4. Dominant Microflora. A total of 88 bacterial isolates were isolated and categorized into different bacterial genera using different biochemical tests such as oxidase, catalase, motility, indole, and gram reaction (Table 7). Consequently, the aerobic mesophilic flora was dominated by Enterobacteriaceae (36\%) followed by Staphylococci spp. (24\%) and Bacillus (19\%). Streptococci (10\%) and Pseudomonas (7\%) were found among the aerobic mesophilic bacteria isolated from beef and contact surface samples (Figure 2).

\section{Discussion}

The educational level of all the meat handlers included in the survey of the present study was below secondary school (Table 1). Most meat handlers (75\%) who participated in the study had a lack of training on hygienic meat processing practices. This could be due to low-scale knowledge of the meat handlers regarding food handling and processing practices [9]. The safety of food can be insured by providing 
TABle 4: Microbial count in fresh beef meat from butcher shops (collected during morning and afternoon time) expressed in log 10 cfu/ $\mathrm{g} \pm$ standard deviation.

\begin{tabular}{lcc}
\hline Bacteria & $\begin{array}{c}\text { Fresh meat samples collected from butcher shops at different time } \\
\text { Morning time } \\
\text { Log cfu/g mean } \pm \text { SD }\end{array}$ & $\begin{array}{c}\text { Afternoon time } \\
\text { Log cfu/g mean } \pm \text { SD }\end{array}$ \\
\hline Total aerobic bacteria & $5.31 \pm 1.27^{\mathrm{b}}$ & $5.47 \pm 1.40^{\mathrm{a}}$ \\
Aerobic spore formers & $3.77 \pm 0.03^{\mathrm{b}}$ & $5.15 \pm 0.26^{\mathrm{a}}$ \\
Total coliform & $4.79 \pm 0.61^{\mathrm{b}}$ & $4.88 \pm 1.29^{\mathrm{a}}$ \\
Enterobacteriaceae & $4.47 \pm 0.55^{\mathrm{b}}$ & $4.84 \pm 0.92^{\mathrm{a}}$ \\
Total fecal coliform & $4.74 \pm 0.91^{\mathrm{b}}$ & $4.94 \pm 0.75^{\mathrm{a}}$ \\
Total Staphylococci & $4.24 \pm 0.16^{\mathrm{b}}$ & $4.78 \pm 0.61^{\mathrm{a}}$ \\
Yeasts and molds & $5.00 \pm 0.41^{\mathrm{a}}$ & $5.07 \pm 0.44^{\mathrm{a}}$ \\
\hline
\end{tabular}

CFU/g: colony-forming unit per gram of beef meat; SD: standard deviation; mean: average of three measurements. Different letters (a,b) in the same rows have significantly different means as determined by JMP Pro 13 a SAS comparison test $(P<0.05)$.

Table 5: Microbial count from contact surface (knife, cutting table, and balance) expressed in $\log \mathrm{cfu} / \mathrm{cm}^{2} \pm$ standard deviation.

\begin{tabular}{lcccccccrr}
\hline \multirow{2}{*}{ Bacteria } & \multicolumn{3}{c}{ Knife $(n=8)$} & \multicolumn{4}{c}{ Log $\mathrm{cfu} / \mathrm{cm}^{2}$ counts from contact surfaces } \\
& Mean & Min & Max & Mean & Min & Max & Mean & Min & Max \\
\hline TAMC & $4.84^{\mathrm{a}}$ & 4.30 & 6.50 & $4.17^{\mathrm{c}}$ & 3.67 & 4.73 & $4.32^{\mathrm{b}}$ & 3.82 \\
ASFC & $4.74^{\mathrm{a}}$ & 4.51 & 5.23 & $3.80^{\mathrm{c}}$ & 3.61 & 3.96 & $3.93^{\mathrm{b}}$ & 3.61 & 4.73 \\
EBC & $4.23^{\mathrm{b}}$ & 3.54 & 5.00 & $4.26^{\mathrm{ab}}$ & 3.65 & 5.70 & $4.08^{\mathrm{c}}$ & 3.56 & 4.97 \\
TCC & $4.41^{\mathrm{a}}$ & 3.69 & 5.56 & $4.23^{\mathrm{b}}$ & 3.79 & 4.89 & $3.96^{\mathrm{c}}$ & 3.67 & 4.56 \\
FCC & $3.93 \mathrm{a}$ & 3.51 & 4.53 & $3.86^{\mathrm{b}}$ & 3.54 & 4.40 & $3.94^{\mathrm{a}}$ & 3.7 & 4.54 \\
TSC & $4.81^{\mathrm{a}}$ & 4.38 & 6.69 & $4.16^{\mathrm{b}}$ & 3.66 & 4.66 & $3.98^{\mathrm{c}}$ & 3.59 & 4.69 \\
YMC & $4.52^{\mathrm{a}}$ & 3.61 & 5.58 & $3.99^{\mathrm{b}}$ & 3.67 & 4.45 & $3.92^{\mathrm{c}}$ & 3.61 & 4.54 \\
\hline
\end{tabular}

Means in the same row with different superscript letters ( $a, b, c$, and ab) are significantly different means as determined by JMP Pro 13 a SAS comparison test $(P<0.05)$.

TABLE 6: Biochemical test for pathogenic microorganisms.

\begin{tabular}{|c|c|c|c|}
\hline Biochemical test & E. coil & S. aureus & Salmonella \\
\hline Catalase & +ve & +ve & +ve \\
\hline Coagulase & - ve & + ve & $-\mathrm{ve}$ \\
\hline Oxidase & - ve & - ve & - ve \\
\hline Triple sugar iron gas, $\mathrm{H}_{2} \mathrm{~S}$, and acid production & Gas and acid produced & Acid production & $\mathrm{H}_{2} \mathrm{~S}$ production \\
\hline Simmons citrate & $-\mathrm{ve}$ & +ve & - ve \\
\hline Lysine iron agar & $\mathrm{H}_{2} \mathrm{~S}$ production & & $\mathrm{H}_{2} \mathrm{~S}$ production \\
\hline Indole & +ve & $-\mathrm{ve}$ & $-\mathrm{ve}$ \\
\hline MRPV & +ve MR and -ve VP & $+\mathrm{ve}$ & +ve MR and -ve VP \\
\hline Gram reaction & $-\mathrm{ve}$ & $+\mathrm{ve}$ & $-\mathrm{ve}$ \\
\hline
\end{tabular}

$-\mathrm{ve}=$ negative result and $+\mathrm{v}=$ positive result.

training to food handlers concerning basic concepts and personal hygiene [30], and 58.33\% of butcher shop workers in Bishoftu, Ethiopia, did not receive training regarding meat handling practice [30]. Different from the present study, about $60 \%$ of the meat handlers in Mekelle had taken training concerned with personal hygiene and food handling practices (Balcha and Gebretinsae [16]).

In this study, only 19\% (3) of the food handlers had skin lesions. In the same way, food handlers who suffer from jaundice, diarrhea, vomiting, fever, sore throat with fever, discharge from the ear, or eye or nose or have visibly infected skin lesions were not allowed to work as food handlers according to the guidelines of WHO [31].
The personal hygiene of meat handlers showed that $75 \%$ wore clean working coats while $56 \%$ used hair covers during serving their customers (Table 1). Thus, the current finding fits with WHO regulation that states, food handlers must dress in clean and suitable clothing [31]. Similarly, Balcha and Gebretinsae [16] also reported that about 58\% and $42 \%$ of the food handlers working at butcher shops in Mekelle wore overalls and hair covers, respectively.

In the present study, the general sanitation statuses of the butcher shops were poor. Similarly, Zerabruk et al. [32] reported the hygienic conditions of most of the butcher shops involved in the study were poor and the meat products were not separated from offal. Ali et al. [33] also reported 


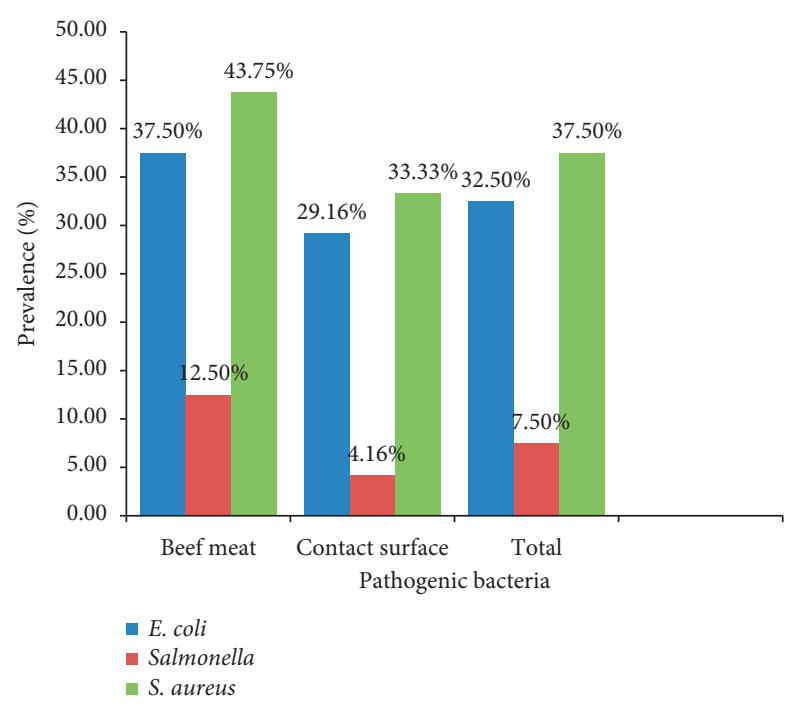

FIgURE 1: Prevalence of pathogenic bacteria in beef meat and swabs from contact surfaces.

TABLE 7: Biochemical test for total aerobic mesophilic bacteria.

\begin{tabular}{lcccccc}
\hline \multirow{2}{*}{ Isolates from PCA } & \multicolumn{4}{c}{ Biochemical test } \\
& Oxidase & Catalase & Motility & Indole & Bacteria genus & Gram reaction and morphology \\
\hline 1 & $-\mathrm{ve}$ & $+\mathrm{ve}$ & $+\mathrm{ve}$ & $-\mathrm{ve}$ & Enterobacteriaceae & Gram-negative and rod \\
2 & $+\mathrm{ve}$ & $+\mathrm{ve}$ & $+\mathrm{ve}$ & $-\mathrm{ve}$ & Staphylococci & Gram-positive and cocci \\
3 & $-\mathrm{ve}$ & $+\mathrm{ve}$ & $+\mathrm{ve}$ & $-\mathrm{ve}$ & Bacillus & Gram-positive and rod \\
4 & $+\mathrm{ve}$ & $-\mathrm{ve}$ & $+\mathrm{ve}$ & $-\mathrm{ve}$ & Streptococci & Gram-positive and cocci \\
5 & $+\mathrm{ve}$ & $+\mathrm{ve}$ & $+\mathrm{ve}$ & $-\mathrm{ve}$ & Pseudomonas spp. & Gram-negative rod \\
6 & $+\mathrm{ve}$ & $+\mathrm{ve}$ & $-\mathrm{ve}$ & $-\mathrm{ve}$ & Micrococcus & Gram-positive and cocci \\
\hline
\end{tabular}

$-\mathrm{ve}=$ negative and $+\mathrm{ve}=$ positive.

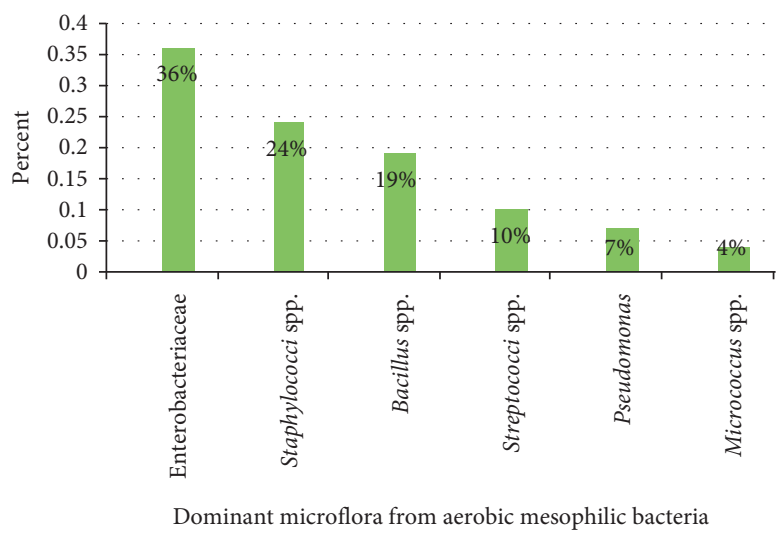

Figure 2: Dominant bacterial genera from aerobic mesophilic flora.

that most of the surveyed butcher shops had poor hygienic conditions concerning the cleaning of their shops and lack of knowledge about disinfection. Poor handling and hygienic practices led to high cross-contamination and recontamination of meat [34]. Most of the meat products in the butcher shops were held on hangers or tables for more than 11 hours. This practice may give sufficient time for the growth of spoilage/pathogenic microorganisms. Ali et al.
[33] reported that cleaning butcher shops with detergent and water once in 24 hours is not enough to maintain hygienic environments in the butcher. In agreement with this study, Muleta and Ashenafi [35] reported that microbes duplicate dramatically if food stays at temperatures between 15 and $45^{\circ} \mathrm{C}$ for greater than $4 \mathrm{hrs}$.

In this study, about $63 \%$ of the butcher shops have cashiers for money collection. Hence, it reduces the possible 
contamination of meat by spoiling microorganisms, which could cause a major health hazard [36]. Differently, Balcha and Gebretinsae [16] reported that $92 \%$ of the food handlers in Mekelle butcheries handled money and serving food, simultaneously.

About $76 \%$ of the consumers included in the study preferred to eat beef meat and $84 \%$ preferred to eat raw meat. Out of the total respondents that preferred meat in its raw state, $84 \%$ of them consumed raw beef which may perhaps be the potential source of spoilage/pathogenic microorganisms. Sisay [37] reported that $55(91.7 \%)$ of the consumers prefer beef to other types of meat, and $42(70 \%)$ prefer eating raw to other types of preparations in Dukem town. Contaminated raw meat is one of the main sources of food-borne illness [38, 39].

In this study, significant microbial counts were detected in all beef meat samples for all groups of microorganisms. However, the highest microbial counts were recorded from beef meat samples collected in the afternoon time (Table 4). Hence, the microbial load from afternoon samples increased by $0.07 \log \mathrm{cfu} / \mathrm{g}$ for yeast and molds and $1.38 \mathrm{log} \mathrm{cfu} / \mathrm{g}$ for aerobic spore formers as compared to the morning samples. The higher microbial count recorded in the afternoon meat samples could be due to an open display of meat for a prolonged period that may favor suitable conditions for microbial growth. A study done in Ghana on the TPC from beef in open markets found the mean TPC to be 6.36-8.47 $\log \mathrm{cfu} / \mathrm{g}$ [40], and Ali et al. [33] reported a higher mean TPC on beef samples from the open market. Similarly, a study conducted in Northern Ghana has reported 2 log differences between morning and afternoon in microbial count from meat samples [17]. Another study conducted in Ghana supermarkets found the mean total plate counts to be 5.01-8.32 log cfu/g [40].

The mean TAM count (5.31 log cfu/g, morning, and 5.47 $\log \mathrm{cfu} / \mathrm{g}$, afternoon) detected from the fresh beef meat in this study was lower than the study conducted by Zerabruk et al. [32] on minced meat from Addis Ababa. However, the average ASF count (3.77-5.15 log CFU/g) recorded in this study was higher than the mean ASF (2.35-2.42 log cfu/g) count reported by Zerabruk et al. [32]. The mean TSFC (4.24-4.78 logs/g) recorded in the present study was lower than TSFC (5.8-7.5 log CFU/g) reported by Tafese [41]. Similarly, a mean count of TAM $( \pm 5.57 \mathrm{cfu} / \mathrm{g})$ from Ghana [42] and a mean count of TAM (7.15 cfu/g) [43] were reported. TAM count obtained from the butcheries during the study exceeded the accepted range $(>5.0 \mathrm{cfu} / \mathrm{g})$ and hence no meat sampled from the butcheries during the study was fit for consumption $[44,45]$.

The mean EC count (4.47-4.84 log cfu/g) and CC count (4.74-4.94 log CFU/g) noticed from meat samples in the current study was comparative to the finding reported by Tafese [41] whereas they were lower than the EC and CC count described by Zerabruk et al. [32]. In general, substantial EC, TC, and FC counts recorded in this study indicate the possible spoilage of the product [46]. According to EC [47] and FSSA [48], the acceptable standards for CC and EBC are $4 \mathrm{cfu} / \mathrm{g}$ and $3 \mathrm{cfu} / \mathrm{g}$ respectively. The highest fecal count recorded in the present study might be due to cross- contamination from the gut of the animals and/or direct fecal contamination [49].

The significant Staphylococci count (4.24 log cfu/g in the morning and $4.78 \mathrm{log} \mathrm{cfu} / \mathrm{g}$ in the afternoon) detected in the present study could be due to inappropriate individual hygiene of food handlers and cross-contamination from skin and utilities under poor sanitary conditions (Table 4). The total Staphylococci count determined from minced meat (4.57 log cfu/g in the morning and 5.77 logs $\mathrm{cfu} / \mathrm{g}$ in the afternoon) at Addis Ababa city was comparative with the present study [32]. Contrarily, the Staphylococci count determined from Arsi cattle meat at Adama (4.98-6.01 log $\mathrm{cfu} /-\mathrm{g}$ ) was higher than this study [50]. The variation may be acquired due to differences in ambient temperature between the study area (Debre Berhan and Adama). The yeast and mold count recorded from beef meat (5.00-5.05 log cfu/g) in this study was lower than the yeast and mold count (5.59-6.04 log cfu/g) noticed from minced meat in Addis Ababa [32].

The mean TAMC noticed from contact surfaces in the present study was slightly lower than the finding reported for the same microorganisms from the knife $\left(6.31 \log \mathrm{cfu} / \mathrm{cm}^{2}\right)$, cutting table $\left(6.32 \log \mathrm{cfu} / \mathrm{cm}^{2}\right)$, and balance (6.43 $\log \mathrm{cfu} /$ $\mathrm{cm}^{2}$ ) [32]. Similarly, Balcha and Gebretinsae [16] reported a higher TAMC of $6.56 \log \mathrm{cfu} / \mathrm{cm}^{2}$ and $6.78 \mathrm{log} \mathrm{cfu} / \mathrm{cm}^{2}$ from the table and knife, respectively. The high TAM count detected from contact surfaces indicated insufficient sanitary conditions in the butcheries.

The mean total Staphylococci count noticed from the knife, cutting table, and weighing balance were 4.81, 4.16, and $3.98 \log \mathrm{cfu} / \mathrm{cm}^{2}$, respectively. The presence of Staphylococci in all the samples in such density indicated unacceptable hygienic standards particularly poor personal hygiene. The Staphylococci count recorded from meat contact in the UK was lower than the current study [51]. The differences in mean count between the two countries may indicate variation in personal hygiene practices. Staphylococcus spp. can be part of normal flora on the skin of humans and animals which can be transmitted from person to product through unhygienic practices [52]. Gracey and Collins [53] also noticed that the meat product with high contact with human hands is associated with reasonable changes of Staphylococci spp.

In this study, the mean total coliform from the knife, working table, and balance was 4.41, 4.23, and $3.96 \log \mathrm{cfu} /$ $\mathrm{cm}^{2}$, respectively, which was higher than the comparative study in the UK [51]. The TCC noticed from knife and table in the present study was lower than the comparative study (TC of knives $5.51 \log \mathrm{cfu} / \mathrm{cm}^{2}$ and TC of working tables 5.34 $\log \mathrm{cfu} / \mathrm{cm}^{2}$ ) conducted in Addis Ababa [32]. Fecal coliform count from cutting board and knife (5.80 and $5.83 \mathrm{log} \mathrm{cfu} /$ $\mathrm{cm}^{2}$ ) of the study conducted by Ayalew et al. [54] in Jijiga city was higher than the present study. The occurrence of cross-contamination and immediate contamination may increase the count.

The mean yeast and mold count recorded from the contact surface $\left(3.92-4.52 \log \mathrm{cfu} / \mathrm{cm}^{2}\right)$ in this study was lower than the study conducted in Jijiga [54]. In general, the high microbial load found on the contact surface may 
indicate the presence of significant cross-contamination among the contact surfaces during the operation.

Among all the 40 samples tested for the presence of pathogenic microbes, 15 (37.5\%) were positive for S. aureus. The high contamination of food with $S$. aureus has been related to inappropriate personal hygiene of the food handlers during handling and processing of meat products [55] and indicates the health hazards of consuming raw meat handled under unsanitary circumstances [25].

Similar to the present study, about $31 \%$ [25] and $29.4 \%$ [54] of the meat samples were positive for coagulase-positive S. aureus and Staphylococcus spp. respectively. However, only $24.53 \%$ of the meat samples were positive for S. aureus [55]. In another study, a higher prevalence rate of $S$. aureus than this study was detected from the contact surface materials in butcher shops [16].

A higher prevalence of E. coli (32.5\%) was also detected from meat and contact surfaces of materials. Hence, the significant positive samples for E. coli noticed in this study showed the unhygienic meat handling practices in butcher shops. Even though the presence of $E$. coli in foods is not always alarming because most strains are harmless and opportunistic, the presence of harmful strains (E. coli O157) can pose gastroenteritis by producing Shiga toxin [58]. Similar to the present study, about 30\% [59] and 32\% [16] were positive for $E$. coli in meat and contacts surface samples collected from butcher shops.

E. coli, Staphylococcus aureus, Salmonella sp., and Proteus sp. were prevalent in beef samples [60]. In the present study, a few numbers of samples collected from butcher shops showed the presence of presumptive Salmonella spp. with a prevalence rate of $7.5 \%$. This finding was supported by [61] that reported in Addis Ababa, about $12 \%$, Salmonella in raw retail meat in Addis Ababa, and in the other study, $3 \%$ of sheep carcasses were positive for Salmonella [62]. The contamination of meat with Salmonella at retail is due to unhygienic carcass transportation, improper loading and unloading, unhygienic meat shop equipment, and personnel [61]. However, the detection of Salmonella in any sample could be due to poor hygiene and sanitary practices through all value chains of the meat supply and indicated the potential risk associated with the consumption of these foods [63]. Salmonella infections continue to be a major public health concern in many countries and the infections are generally foodborne [64].

The microbial flora recovered from beef meat and contact surface were dominated by Enterobacteriaceae, Staphylococci, and Bacillus spp. Likewise the microflora of "kitfo" was dominated by the same spp. [35]. In another study, Dabessa [65] also reported the dominance of $\mathrm{Ba}$ cillus, Staphylococcus, and Enterobacteriaceae spp. in household meat in Jimma. Similar findings reported that bacteria isolates from minced meat were dominated by E. coli, coliform, S. aureus, Streptococcus spp., and nonlactose fermenter bacteria [66]. Bacteria isolated from butcher shops' hanged meat and minced meat were Enterobacteriaceae, Staphylococcus, and Streptococcus species [67].
Bacterial identification was conducted by standard biochemical methods [68]. For Gram-negative organisms, further identification tests included oxidase, citrate, triple sugar iron, and catalase were done [69]. Discrete colonies were subcultured into fresh agar plates aseptically to obtain pure cultures of the isolates and used for further identification using biochemical methods [70]. Bacterial identification was conducted by standard biochemical methods (Manual of Clinical Microbiology, 2002). A biochemical tests were done for Gram-negative organisms, by oxidase, citrate, triple sugar iron, and catalase according to Bauer et al. [59, 67, 68].

\section{Conclusion}

The major factors that contributed to the contamination of meat were low-level awareness of hygienic practices, unproper handling of paper currency, and poor sanitation of the butcher shops. In this study, a significant microbial load of spoilage microbes was noticed in beef meat and swabs from contact surfaces. However, the highest microbial loads were detected from the meat samples collected in the afternoon time. Significant samples were positive for pathogenic microbes that may lead to the risk associated with the consumption of the products.

\section{Data Availability}

The experimental data used to support the findings of this study are included within the article.

\section{Conflicts of Interest}

The authors declare that there are no conflicts of interest regarding this paper.

\section{Authors' Contributions}

Tefera Atlabachew was involved in acquisition and analysis, interpretation of data, and drafting of the work. Jermen Mamo participated in conception, acquisition, analysis, interpretation of data, drafting of the work, analysis, and substantive revision of the work. The authors agreed to publish this research article.

\section{Acknowledgments}

The authors would like to acknowledge the Department of Biology, College of Natural and Computational Science, Debre Berhan University, for funding, facilitation of laboratory space, and provision of other facilities.

\section{References}

[1] European Food Safety Authority (EFSA), "Scientific report of the scientific panel on biological hazards on the request from the commission related to Campylobacter in animals and food stuffs," Annex to the EFSA Journal, vol. 173, pp. 1-105, 2005.

[2] WHO, WHO Surveillance Programme for Control of Foodborne Infections and Intoxications in Europe, 7th Report 19931998, WHO, Geneva, Switzerland, 2000. 
[3] ICMSF, Microorganisms in Foods 7. (Management), Kluwer Academic/ Plenum Publishers, New York, NY, USA, 2002.

[4] A. Maripandi and A. A. Al-Salamah, "Multiple antibiotic resistance and plasmid profiles of Salmonella enteritidis isolated from retail chicken meats," American Journal of Food Technology, vol. 5, pp. 260-268, 2010.

[5] A. A. Kraft, Psychotropic Bacteria in Foods: Diseases and Spoilage, CRC Press, Boca Raton, FL, USA, 1992.

[6] M. García-López and M. Prieto, The Physiological Attributes of Gram Negative Bacteria Associated with Spoilage of Meat and Meat Products, FAO, Colosseum, Italy, 1998.

[7] S. Rawat, "Food spoilage: microorganisms and their prevention," Asian Journal of Plant Science and Research, vol. 5, no. 4, pp. 47-56, 2015.

[8] S. Datta, A. Akter, I. Shah et al., "Microbiological quality assessment of raw meat and meat products, and antibiotic susceptibility of isolated Staphylococcus aureus," Agriculture, Food and Analytical Bacteriology, vol. 2, pp. 187-194, 2012.

[9] A. Gashe, K. Alemu, and D. Haile, "Factors affecting food handling Practices among food handlers of Dangila town food and drink establishments, North West Ethiopia," BMC Public Health, vol. 14, p. 571, 2014.

[10] S. Nel, J. F. R. Lues, E. M. Buyus, and P. Venter, "Bacterial populations associated with meat from the deboning room of a high throughput red meat abattoir," Meat Science, vol. 66, pp. 667-674, 2004.

[11] CDC, Preliminary food net Data on the Incidence of FoodBorne Illness-Selected CDC or the US Department of Health and Human Service, US Food and Drug Administration, Washington, DC, USA, 2003.

[12] A. H. M. Yousuf, M. K. Ahmed, S. Yeasmin, N. Ahsan, M. Rhman, and M. M. Islam, "Prevalence of microbial load in shrimp, peanuts modern and prawn, Macro brachium Rosen Berger from Bangladesh," World Journal of Agriculture and Soil Science, vol. 4, pp. 852-855, 2008.

[13] M. Birhaneselassie and D. Williams, "A Study of Salmonella carriage among asymptomatic food-handlers in Southern Ethiopia," International Journal of Nutrition and Food Sciences, vol. 2, no. 5, pp. 243-245, 2013.

[14] WHO, Developing and Maintaining Food Safety Control Systems for Africa Current Status and Prospects for Change: Second FAO/WHO Global Forum of Food Safety Regulators Regional Office for Africa, WHO, Bangkok, Thailand, 2004.

[15] CSA, Central Statistical Authority, Federal Democratic Republic of Ethiopia, Statistical abstract, M.sc. thesis, CSA, Addis Ababa, Ethiopia, 2012.

[16] E. Balcha and H. Gebretinsae, "Assessment of bacteriological quality of meat contact surfaces in selected butcher shops of Mekelle city, Ethiopia," Journal of Environmental Occupational Science, vol. 2, no. 2, pp. 61-66, 2013.

[17] A. K. Obeng, F. S. Johnson, and S. O. Appenteng, "Microbial quality of fresh meat from retail outlets in tolon and kumbungu districts of the northern region of Ghana," International Journal of Science and Technology, vol. 2, pp. 423-427, 2013.

[18] ISO/TS 11133-1, Microbiology of Food and Animal Feeding Stuffs. Guidelines on Preparation and Production of Culture Media. Part 1: General Guidelines on Quality Assurance for the Preparation of Culture Media in the Laboratory, ISO, Geneva, Switzerland, 2009.

[19] American Public Health Association, Standard Methods for the Examination of Water and Wastewater, APHA, Washington, D.C, USA, 22nd edition, 2012.
[20] United States Pharmacopeial Convention, The United States Pharmacopeia, Vol. 61, The United States Pharmacopeial Convention, Rockville, MD, 31st edition, 2007.

[21] ISO 4832, Microbiology-General Guidance for the Enumeration of Coliforms-Colony Count Technique, International Organization for Standardization (ISO), Geneva, Switzerland, 1991.

[22] Nordic Committee on Food Analysis (NMKL), Coliform bacteria and Escherichia coli in Foods, NMKL Method No. 68, Nordic Committee on Food Analysis, Oslo, Norway, 4th edition, 1993.

[23] HPA, Determination of Salmonella spp. Standard Operating Procedure, HPA (Health Protection Agency), London, UK, 2003.

[24] Nordic Committee on Food Analysis (NMKL), Salmonella Bacteria, Detection in Foods, NMKL Method No. 71, Nordic Committee on Food Analysis, Oslo, Norway, 4th edition, 1991.

[25] K. Tofic, "Prevalence of Staphylococcus aureus in beef carcass and its source of contamination at Addis Ababa abattoir, Ethiopia," Korean Journal of Food Science, vol. 34, pp. 7-13, 2013.

[26] D. H. Bergey, J. G. Holt, and N. R. Krieg, Bergey's Manual of Determinative Bacteriology, Lippincott Williams \& Wilkins, MI, USA, 9th edition, 1994.

[27] P. Harley, Laboratory Exercise in Microbiology, pp. 1-42, The McGraw-Hill, New York, NY, USA, 2002.

[28] G. Gregerson, "Rapid method for detection of gram-positive and gram-negative bacteria," European Journal of Applied Microbiology, vol. 5, pp. 123-127, 1978.

[29] A. E. Brown, Benson's Microbiological Application: Laboratory Manual in General Microbiology, McGraw-Hill, New York, NY, USA, 2009.

[30] A. Bersisa, D. Tulu, and C. Negera, "Investigation of bacteriological quality of meat from abattoir and butcher shops in Bishoftu, Central Ethiopia," International Journal of Microbiology, vol. 2019, Article ID 6416803, 8 pages, 2019.

[31] WHO, Essential Safety Requirements for Street-Vended Foods: Food Safety Unit Division of Food and Nutrition, WHO, Bangkok, Thailand, 1996.

[32] K. Zerabruk, N. Retta, D. Muleta, and A. Tesfaye, “Assessment of microbiological safety and quality of minced meat and meat contact surfaces in selected butcher shops of Addis Ababa, Ethiopia," Journal of Food Quality, vol. 2019, Article ID 3902690, 9 pages, 2019.

[33] N. Ali, A. Farooqui, A. Khan, and S. Kazmi, "Microbial contamination of raw meat and its environment in retail shops in Karachi, Pakistan," Journal of Infection in Developing Countries, vol. 4, no. 6, pp. 382-388, 2010.

[34] FAO, "Meat and meat products," 2004, http://www.fao.org/ DOCREP/004/T0562E/T0562E00.htm.

[35] D. Muleta and M. Ashenafi, "Salmonella and Shigella and growth potential of other food-borne pathogens in Ethiopian street-vended foods," East African Medical Journal, vol. 78, pp. 576-580, 2001.

[36] G. Girma, T. Ketema, and K. Bacha, "Microbial load and safety of paper currencies from some food vendors in Jimma Town, Southwest Ethiopia," BMC Research Notes, vol. 7, no. 1, p. 843, 2014.

[37] Z. Sisay, "Assessment of the contamination of beef with salmonella and knowledge, attitudes, and beef handling practices along beef supply chain in Dukem town, Ethiopia master's thesis," 2017. 
[38] S. G. Bhandare, A. T. Sherikar, A. M. Paturkar, V. S. Waskar, and R. J. Zende, "A comparison of microbial contamination on sheep/goat carcasses in a modern Indian abattoir and traditional meat shops," Food Control, vol. 18, no. 7, pp. 854-858, 2007.

[39] B. Podpecan, A. Pengov, and S. Vadnjal, "The source of contamination of ground meat for production of meat products with bacteria Staphylococcus aureus," Slovenian Veterinary Research, vol. 44, pp. 24-30, 2007.

[40] A. H. Francis, A. G. Abraham, and A. Victoria, "Microbiological and parasitological quality of local beef retailed in Accra and radiation sensitivity of Salmonella sp," International Journal of Current Microbiological and Applied Sciences, vol. 4, no. 4, pp. 86-96, 2015.

[41] F. Tafesse, G. Desse, K. Bacha, and H. Alemayehu, "Microbial quality and safety of street vended raw meat in Jijiga town: southeast Ethiopia," African Journal of Microbiology Research, vol. 8, pp. 3867-3874, 2010.

[42] F. Adzitey, G. A. Teye, W. N. Kutah, and S. Adday, "Microbial quality of beef sold on selected markets in the tamale metropolis in the northern region of Ghana," Livestock Research for Rural Development, vol. 23, pp. 54-63, 2011.

[43] M. D. Ahmad, A. Sawar, M. I. Najeeb et al., "Asse ssment of microbial load of raw meat at abattoir and retail shops," Journal of Animal and Plant Sciences, vol. 23, pp. 745-748, 2013.

[44] Microbiological Criteria for Food Stuffs-Part 1.GCC, Gulf Region Standards, Riyadh, Saudi Arabia, 2000.

[45] Codex Alimentary Commission (CAC), Code of Hygienic Practice for Meat, CAC/RCP 58-2005, Codex Alimentary Commission, Geneva, Switzerland, 2005.

[46] M. R. Adams and M. O. Moss, Food Microbiology, RoyalSociety of Chemistry, Guildford, UK, 2nd edition, 2000.

[47] European Commission regulation (EC), "Microbiological criteria for foodstuffs," 2005, https://scholar.google.de/ scholar?q=COMMISSION+REGULATION+\%28EC\% $29+\mathrm{No}+2073 \% 2 \mathrm{~F} 2005 \& \mathrm{btnG}=\& \mathrm{hl}=\mathrm{en} \& \mathrm{as} \_\mathrm{sdt}=0 \% 2 \mathrm{C} 5$.

[48] Food Safety and Standard Authority of India, Regulation, Microbiological Standards for Meat and Meat Products (Food Products Standards and Food Additives), Food Safety and Standard Authority of India, New Delhi, India, 2011.

[49] M. E. Nyenje, C. E. Odjadjare, N. F. Tanih, E. Green, and R. N. Ndip, "Foodborne pathogens recovered from ready-toeat foods from roadside cafeterias and retail outlets in Alice, eastern cape province, South Africa: public health implications," International Journal of Environmental Research and Public Health, vol. 9, no. 8, pp. 2608-2619, 2012.

[50] A. Gebeyehu, M. Yousuf, and A. Sebsibe, "Evaluation of microbial load of beef of Arsi cattle in Adama town, oromia, Ethiopia," Journal of Food Processing \& Technology, vol. 04, no. 6, pp. 1-6, 2013.

[51] C. L. Little and J. D. Louvois, "The microbiological examination of butchery products and butchers' premises in the United Kingdom," Journal of Applied Microbiology, vol. 85, pp. 177-186, 1998.

[52] J. R. Postgate, Microbes and Man, Cambridge University Press, Oxford, UK, 2000.

[53] J. F. Gracey and D. S. Collins, Meat Hygienepp. 96-128, Bailliere Tindall, London, UK, 9th edition, 1992.

[54] H. Ayalew, A. Berhanu, B. Sibhat, and B. Serda, "Microbiological assessment of meat contact surfaces at abattoir and retail houses in Jigjiga town, Somali national regional state of Ethiopia," ISABB-journal of Food and Agricultural Science, vol. 5, no. 3, pp. 21-26, 2015.
[55] N. Cohen, H. Ennaji, M. Hassa, and H. Karib, "The bacterial quality of red meat and offal in Casablanca (Morocco)," Molecular Nutrition \& Food Research, vol. 50, no. 6, pp. 557-562, 2006.

[56] G. Pesavento, B. Ducci, N. Comodo, and A. L. Nostro, "Antimicrobial resistance profile of Staphylococcus aureus isolated from raw meat: research for methicillin-resistant Staphylococcus aureus (MRSA)," Food Control, vol. 18, no. 3, pp. 196-200, 2007.

[57] W. Birhanu, W. Sisay, and B. Gashaw, "Assessment of microbiological quality and meat handling practices in butcher shops and abattoir found in gondar town, Ethiopia," International Journal of Microbiological Research, vol. 8, no. 2, pp. 59-68, 2017.

[58] A. H. Kebede, Z. Alebachew, F. Tsegaye et al., "The first population-based national tuberculosis prevalence survey in Ethiopia," International Journal of Tuberculosis and Lung Disease, vol. 18, no. 6, pp. 635-639, 2014.

[59] T. Kebede, B. Afera, H. Taddele, and A. Bsrat, "Assessment of bacteriological quality of sold meat in the butcher shops of Adigrat, Tigray, Ethiopia," Applied Journal of Hygiene, vol. 3, no. 3, pp. 38-44, 2014.

[60] D. H. Tambekar, V. J. Jaiswal, D. V. Dhanorkar, P. B. Gulhane, and M. N. Dudhane, "Identification of microbiological hazards and safety of ready-to-eat food vended in streets of Amravati City, India," Journal of Applied Biosciences, vol. 7, pp. 195-201, 2008.

[61] G. Ejeta, B. Molla, D. Alemayehu, and A. Muckle, "Salmonella serotypes isolated from minced meat beef, mutton, and pork in Addis Ababa, Ethiopia," Revue de Medecine Veterinaire, vol. 155, no. 11, pp. 547-551, 2004.

[62] J. K. Kumar, A. K. Sharma, and P. R. Kulkarni, "Survey of Indian foods for Staphylococcus aureus," Indian Veterinary Journal, vol. 78, pp. 875-878, 2001.

[63] J. M. Jay, Modern Food Microbiology, Aspen Publishers, Frederick, MD, USA, 1996.

[64] M. Helms, S. Ethelberg, and K. Mølbak, "International Salmonella Typhimurium DT104 Infections, 1992-2001," Emerging Infectious Diseases, vol. 11, 2005.

[65] A. Dabessa, "Evaluation of home slaughtered meat quality used for human consumption at household and food seller house in Jimma," Journal of Medical Sciences, vol. 13, pp. 779-784, 2013.

[66] S. Clarence, C. Obinna, and N. C. Shalom, "Assessment of bacteriological quality of ready-eat food (Meat pie) in Benin City metropolis, Nigeria," African Journal of. Microbiology Research, vol. 3, pp. 390-395, 2009.

[67] S. G. Olukole and O. O. Kehinde, "Microbial studies of table scrapings from meat stalls in ibadan metropolis, Nigeria: implications on meat hygiene," African Journal Of Biotechnology, vol. 9, 2010.

[68] American Society for Microbiology Press, Manual of Clinical Microbiologypp. 442-631, American Society for Microbiology Press, Washington, DC, USA, 7th edition, 2002.

[69] A. W. Bauer, W. M. Kirby, J. C. Sheriss, and M. Turc, "Antibiotic susceptibility testing by standardized single method," American Journal of Clinical Pathology, vol. 45, pp. 493-496, 1996.

[70] CLSI, A Standard For Global Application Developed Through The Clinical And Laboratory Standards Institute Consensus Process, Vol. 28, CLSI, Pittsburgh, PA, USA, 2008. 